大阪大学医学部，第 1 解剖学教室 (主任 : 高木教授).

1st Dept. of Anat., Med, School, Osaka Univ. (Director: Prof. K. TAKAGI).

\title{
人胎児小腸上皮の分化に就的て*
}

\section{Studies on the Differentiation of Intestinal Epithelium in Human Embryo.}

\section{出田艶子 Tsuyako IZUTA.}

〔昭和 29 年 6 月 17 日原稿受付.〕

人胎児は胎生期中母体飞より養われ，物質交換は胎盤を介して行われる を以って，消化管，なかんずく小腸の機能的活動は少ないと思われるが， 肝飞於いては巳飞胎生 5 ケ月飞て胆汁が証明され，また腸管内飞は 5 ケ月 末期で胎䔬の存在する等の事実を考光る時，胎生期間中と雖る腸管は，あ る程度の機能を営えでいるものと解してよかろう。而して出生後小腸は直 ちと消化吸收の作用を発輝しなけれげならない，従って胎生期飞於ける小 腸上皮の発生分化を追及することは，小腸機能を知る上滑味あること〉 思われる，文献とよれば，喟乳動物消化管の発生学的研究はその業績多く， また人胎罗に就いても Meckel（1817）を始めとし Kölliker（1861), Berry （1900），Tandler（1902），大森（1930）及び原（1931）等は小腸上皮の発 生，絨毛の形成に関し，有馬（1927）は上皮細胞の微細構造を報告してい る．然し氏等の記載は極めて概括的か或は限局した時期の所見である。私 は暴に公表した胎生期肝細胞の研究飞並行して，小腸上皮の分化を，主と して細胞微細構造の面より追及し，之飞組織化学的所見をも加えて，小腸 分化の変遷を，胎令を追って明かにしたいと企図した。

\section{I. 研究材料と方法.}

研究材料は新鮮なる人胎児50例を選び， 3 ケ月迄の幼若胎兆はとのま」 之を連続切片となし，3ケ月以上の胎児飞於いては，可及的速やか飞開腹 して腸管を摘出し，部位を略々一定して取材し，縦及び横断切片を作成し た．而して用いた固定並びそ染色法に就いては，前編「肝組織の発生学的 研究」に於いて記載せしを以って省略する。

\section{II. 所 見.}

胎令 8 週 $(2$ 个月). 身長 $1.2-2.0 \mathrm{~cm}$.

* 本研究慗旨は昭和 28 年 5 月，第58回日本解剖学会総会及び同年10月，第14回解剖 学会近畿地方会に於いて発表した。 
この時の腸管内腔は裂際状を呈し，内面を被う粘膜上皮は，細胞の境界 不明瞭で，核は上皮の中尖部飞於いて重積する（図 1).このとき核は概ね 梢円形で，その長軸は粘膜面飞対し垂直の位置をとるものが多い。また核 の中には直接分裂を思わせるものも認められる。次に胞体中には多数の空 胞があり，これ等は上皮表面及び底面に近い処では融合の傾问を示してい る，脂肪及び糖原染色飞ては之等空胞は全く染まらない，Mitochondria （以下ミトと略記する）は細い短糸状が主体をなし，概ね縦飞配列するが， 上皮表面に近い処では桿状が多く，水平或は斜め等種々の方向に並ぶ。小 皮縁は痕跡をも認めない.

胎令 10 週（3ケ月初期）. 身長 $2.5-3.5 \mathrm{~cm}$.

上皮は著しい肥厚を示すが細胞境界は依然不明である（眓 2 ）。核も亦 增数と同時に長さを增し，互飞接触を保って縦飞配列し，核小体も増大す る. 次に上皮の肥厚と比例して胞体中の空胞が著しく増数し，特飞上皮基 底部於いては融合した大空胞が集る。ミトは細い糸状が主体であるが， 内腔側では短桿状及び顆粒状が多い，小皮緑は尚認められない，このとき 間葉層飞於いては，上问性発育と血管新生が顕著で，早くも少数の絨毛原 基が認められる.

胎令 12 週 ( 3 ケ月末期). 身長 $4-6 \mathrm{~cm}$.

前者と僅か こ週の差に過ぎないが，所見には一段の変化が見られ，この

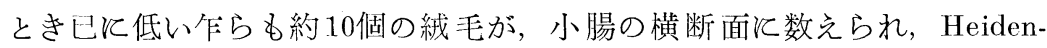
hain の所謂双胎， 3 胎絨毛が胃られる。一方上皮は前者飞比して著しく非 薄となり，その構造は絨毛の部位によって差異がある。即ち絨毛基底部に 於いては細胞境界は依然不明で（図 3 ），略々』層飞並ぶ核が見られ，小 皮䋎は部分的に認めるに過ぎない，空胞は一般に小さく核上部及び㤥下部 に多く，ミトは桿状を主体とする，以上の所見はむしろ 8 週例飞近い。䋘 毛中头部にあっては，内腔側では細胞境界瓜よ゙判然し（困 4)，その表面 は小皮縁によって被われるが，との他の部位では境界な招不明瞭のところ が多い，然し核の重積は殆ど見られず，こっに於いて上皮は明かに単層で あることが判かる. 斯くの如く核の単層配列と同時に概ね細胞上部に位し， 空胞は逆に基瓯側飞集合して厚い層を形成する。ミトは核下部では数少な く，その形状は細い糸状乃至桿状を呈するが，核上部では顆粒状または短 桿状で，密集して閧染層を現わし，これと小皮縁との間に狭い空胞層を有 する，絨毛尖端部では細胞の境界は全般的に判然し(図 5 ), 整然たる単層 円柱上皮となる。このとき注目すべきは核の位置で，絨毛中央部とは反対 飞基底側に核が配列し，内挖側飞空胞が集まる。またミトにも異変があっ 
て，上記の如く核上部に密集することなく，この部の空胞群の周囲に配列 する。これら核上部の空胞中飞，粗大䟴染頪粒が大小の集㳡をなして浮游 していることも特筆すべきである。他面この時期と於ける新所見は，散在 性に杯細胞及び基成顆粒細胞が出現することである．前者は粗大濃染顆粒 とて充満し，このとき已特有の形状を示している。また後者は種々なる 程度の発育像を示し, 微細顆粒僅少の小形細胞から, 細胞基诋部が独得の 微小顆粒にて充満する成熟型飞至る各種段階のものを認める. 本細胞飞就 いては項を改めて後述する．斯くの如く小皮縁の完成と相俟って，䋐毛尖 端部では上皮の分化が一応の完成を示するのと思われる。

胎令 $14-16$ 週（4ケ月）. 身長 $10-15 \mathrm{~cm}$.

絨毛は 3 ケ月例より稍々長くなると同時に増数し，横断面にて約 25 個を 数え得る。これと並行して細胞境界は, 絨毛基底の小部を除いては略々判 明する。また小皮縁は全域飞亘り完成される。次に細胞は空胞多く明視性 で，核は胞体の中尖または基底部に位置を占める。こっで注目すべきは䋐 毛尖端部に於いて，核上部に濃染する粗大顆粒を認めることである．この ものは前記の図 5 亿見た濃染顆粒の増数したものと思われる。いま試みに methyl green-pyronin 染色を施したところ, 眓 6 に示す如く pyronin 染 性物質である，從ってこのものはリボ核酸（R.N.A）であることは疑を 容れない。 ミト核上部では主として顆粓状，短桿状で，核下部に於いて は糸状，桿状をを呈する。尚䄉毛基底部にては図4 亿見る如きミトの密集 層を小皮緑下飞認める.

胎令 $18-20$ 週 $(5$ ケ月). 身長 $17.5-20 \mathrm{~cm}$.

絨毛の長さは前例飞比して大差はないが，その形態は次第に整い，且つ 増数して横断面に於いては 35 内外を数元る（図 7 ）. 上皮細胞の境界は全域 飞亘り明瞭となり，細胞は増大し，核上部及び核下部には空胞が多数認め られる，核は䄉毛尖端部では細胞中点飞, 䋐毛基底部では細胞底部に位置 する．本例で著明なる変化は，杯細胞の急激なる増数で，上皮細胞 $3-4$ 個に 1 個の割合で認め得る。尚絨毛尖端部及び中圤部飞於いて，核の上部 飞前記 R. N. A. 顆粒が証明される. ミトは核上部にては短桿状，顆粒状が 多く，小皮縁下では稍々密集している，その他聚落を形成するものも散見 される。これに反し核下部にては桿状，糸状を呈する。

胎令 $21-23$ 週（6ケ月）。身長 $21-26 \mathrm{~cm}$.

絨毛は著しく長さを増し, 且つ高度に増数し, 横断面で60一65を算する. この結果絨毛間腔は甚だしく狭くなる。而してこの時期には絨毛中央部よ り尖端部に於いて, 細胞中飞鉄へマトキンリンとて濃染する大小様々の滴 
状或は塊状物が認められる（罒８）。 また前例迄胞体中に多く認められた 核上部の空胞は，この時殆ど影を没する。この濃染性の滴状物は mucicarmin 染色, Feulgen 反忘, pyronin-methyl green 染色及び ribonuclease 試験等の結果 R. N. A. であることが確定せられた。而してこれが多量なる 時は核が压迫されて半月状を呈し， methyl green とて濃染され且つ棏造は 不鮮明である（罒 9 と11）。乙の時のミトは非常は数少く, 稍々太い顆粒状, 短桿状が主体をなし（罒10），稀飞滴状物の周囲で聚落を形成している. 他方 6 ケ月の終りと至り初めて Paneth 氏細胞の出現を見る（図12と13）. 而もこのとき已飞特有の分泌顆粒をもつもの，或は空胞を有する所謂成熟 型が，幼若型と思われる細胞と共飞認められる.

胎令 $25-27$ 週（7ケ月）。身長 $28-30 \mathrm{~cm}$.

7 ケ月の初期では 6 ケ月例と大差ないが，末期になると紱毛の增数は一 段と顕著で，横断面にて70以上を数觉ることが出来る，との結果䋐毛は互 飞接触し，その間腔は間隙を認める飞過ぎない，次飞上皮内に於いて，核 上部に多量証明された R. N.A.が，このとき全く消失していることは特筆 そ価する（四14）。このため核は細胞の中央より稍々上位を占め，その下 部に多数の空胞が占居する。またミトは増数して顆粒状，長短桿状をなし， 核の上部及び下部に集合する傾向を示す（図15）。 またこの時杯細胞も多 数見られ, Paneth 氏細胞もかなり増数している.

胎令 37 週 (9ケ月). 身長 $47 \mathrm{~cm}$.

前例飞比し絨毛は更に発達し，且つ著しい増数を来たす。而してこの時: 期飞於ける主なる変化は，細胞が大きくなり，7ケ月迄見られた胞体内空 胞が殆ど消失して，只核上部と細胞基底側飞少数認めると過ぎない（四 16）。た小皮縁は著明なる肥厚をきたし，核は細胞中央部に位置する。

ミトは稍々䊼細となり愈々数を增し，主として顆粒状，長短桿状で，核上 部，核下部飞密飞分布する（図17）。杯細胞は一段と増数して腸腺内飞も 散在し, Paneth 氏細胞も空胞を有するものが多い。

基底顆粒細胞飞就いて。

細胞基底部に多数の微小顆粒を有する所謂基底顆粒細胞に関しては，多 数の業績が発表されているが，尚不明の点が少なくない．即ち第 1 は本細 胞の上端が腸の内腔飞達しているか否か，第っは本細胞は移動性があって， 結締織から上皮の中光，また反対飞上皮から結締織飞移動する，第 3 は本 細胞が如何なる機能を有するか等に就いて，種々論議されているが，未だ 明確なる解決飞至っていない，私は人胎児小腸上皮の組織発生を追及する 
そ際して，これ等の疑点に対し或程度の解明を与える所見を得たのでこ〉 に附記する。

本細胞を初めて認めたのは胎生12週（3ケ月の終り）からで, ひろく䋐 毛中央部より基底部にかけて存在する。而もとの出現初期から早くも幼若 型と思われるものより，明かな成熟型まで各種の発育像を認める．然し最 も多いのは図 1 と 2 亿示す如きで, 核は細胞上端に近く位置し, 胞体下半 部には微小顆粒が充満する. か〉る微小顆粒充満の細胞にあっては, 胞体 上端が上皮の表面に達していることは殆どない，次いで多い細胞は図 3,4 , 5 で, 胞体下半部の微小顆粒は著しく減少し，こ〉飞明視性内容を有する 空胞と繊細なミトが認められる，とれらの細胞とあっては丈高く円錐状を 呈し，その狭き上端を以って内腔表面に露出する. か子る細胞はその内部 構造, 特飞空胞の含有量と微小顆粒, ミトの関係等から, 機能的には図 1 と2よりも一歩進んだ段階にあるものと思われる. 而して胞体下半部に空 胞の多いことは, 本基低顆粒細胞の機能の中心が, 細胞下半部にあること を物語っている. 次に図 $6,7,8$ は, 本細胞の起源飞向って有力なる示唆 を与光る. 即ち後の 2 者は明かに本細胞の幼若型と判断せられるもので, 前記 1 と2の間に種々の中間型を認める。然し最も興咮あるは図 6 で，上 皮中に介在する幼若型と識別困難なる細胞を，上皮下の結䋨織中飞認める ことである. 更にこれに類似の細胞が，上皮内え進入するかの如き所見に も屢々接する.

\section{III. 綜 括 と考察.}

胎生 8 週（こケ月の終り）飞於ける小腸上皮は, 細胞間の境界は全然認 められず，Berry の報告と同様で核がっー3層飞重積を示しているに過ぎ ない, か小る重層観は, 絨毛形成の開始せられる12週頃迄継続する。 いま この期に至る迄の粘膜上皮を見るマ, 増殖肥厚が急激に進展し, 大約 10 週 にて内腔は一時上皮性閉寒をきたす。 また細胞内に於いては空胞が激増し， 上皮の肥厚飞協力するもの」様である. か〉る内腔の上皮性閉塞及び上皮 内の空胞形成は，已に Tandler，続いて Kreuter（1905）等の報告飞もあ るところで，氏等は之を以って発育途上に於ける生理的現象となしている. か〉る上皮性閉塞は極めて短期間にのみ見られ，早くも12週に至れば.上皮 の融解現象により再び通過性をるち, 折から発生する䋐毛形成をして容易 ならしめる様である。

次に䄉毛は上に述べた如く 12 週にて俄かに現われ，而子小腸の大部分に 於いて認められる。いこの期の幼若䋘毛を基底部より尖端部に向って追 
及すれば，小腸上皮の分化過程を略々明かとすることが出来る。即ち䋐毛 基底部にあっては，上皮細胞の境界は不明で，重層観を呈するに反し，絨 毛中尖部にては単厤配列を示し，内院表面にはしに小皮縁が形成せられる。 また細胞内部にありては，核は上端飞近く配列し，空胞恬細胞下半部を占 める等分化の進展目ざましいものがある。然し細胞境界は内腔側を除さ依 然不明である。これより絾毛尖端部と進めば初めて細胞境界は判然し，完 全なる単層门柱上皮となり，核なた整然たる酒列を示して上皮底面に接し て位し，空胞は細胞上半部を占める。以上は䄉毛各部の代表的所見である が，これらは夫々中間型を以って相移行するとより，この期の 1 絨毛は小 腸上皮の発生過程を説明して余りあるものがある。これらを綜合すれば， 絨毛原基の形成は小腸上皮の薄くなること〉, 間葉看の上向発達及び血管 の新生との協力によって行われ，これに続く䋐毛の発達は，上皮の重層観 から単層化することが主役を演ずるものであることがわかる，而してこの 過程に於いて核が一時内挖側に位し，のち基底側に位置を変じ, 空胞はこ れと逆に動くことの意義は判明しないが, 細胞の境界が㤥の存在する内挖 側から始まり，また小皮縁もこ〉出来ることは，細胞機能の中心がこの とき細胞上端にあることを物語っている.

更にミトの形状及び配列は，この考えに有力なる示唆を与える. 即ちミ トは細い糸状乃至桿状であるが，核が上位を占める時には核上部に密集し て浱染層を形成し，而もミトは短桿状乃至顆粒状をなして，胎生期として は見られない特殊配列を示している。 このことも亦細胞上端飞機能の中心 のあることを暗示している。とれれ組織発生学上興味あるは, 絨毛中头部 飞於ける所見で，この様な時期を経て初めて尖端部に見る如き構造像を呈 すると至る。

かくて 4 ケ月（16週）になると䋐毛の形態略々一定し，上皮に於いても 亦部分的差異はなくなり，小皮縁も緁毛全体に認められるが，他面には短 かい幼若絨毛が，長い䄉毛の間に多数介在する。爾後絨毛の増数及び発育 が急激飞進み，4ケ月にて約25個を数光た絨毛は 5 ケ月で35内外，6ケ月 で60一6万，7ケ月では70以上となる。 この様と絨毛は増数の一途を辿るが， 上皮の構造は䋐毛とょって種々で, 宛ら小腸上皮の分化過程の縮困の様で ある。

一方飞於いて12週に初めて現われた杯細胞は，5ケ月頃から急激飞増加 し，長い絨毛では10-1万個を数える．然ると殆ど時を同じくして現われた 基底顆粒細胞は，後半期にては前半期よりも却って減少したかの様に見党 る.これは恐らく絨毛の発育と並行した増数を示さない為めであろう。そ 
のほか 6 ケ月では初めて Paneth 氏細胞が現われるが，このとき已典型 的の顆粒を有するもの，顆粒の空胞化しているもの，或は幼若型等があっ て，細胞構造に機能的動態を認める。而して爾後增数し 9 ケ月に於いては, 空胞を有するものが多いととは機能の進展を物語っている.

こっマ特筆すべきは胎生 3 ケ月の終りより上皮細胞の核上部飞濃染する 粗大顆粒の出現である。この顆粒は 6 ケ月にて急激に増大して滴状をなし, また増数して凝塊状を呈する。このものは絨毛尖端部より中央部にかけて 特に大きく，これがため核を圧迫し変形せしめるものも見られる。然ると 7 ケ月の終り飞至れば全く影を没する。この滴状物はとの反応から， R. N. A. が主体を占めていることは疑を容れないが，かくも大量に現われたも のが，7ケ月末期に消失することの意義は明かでないが，人胎児肝細胞飞 於いても，これと殁ど時を同じくして細胞質 R. N. A. が一時的飞減少する こと〉併せ考えると, 発育途上の小腸上皮細胞飞於ける機能の一転換期で はないかと思われる。

一方上皮細胞ミトは糸状乃至桿状が主体で，胎令による差暴は少ないが， その分化発育飞従って変化することは明かである. 即ち10週より20週（5 ケ月終り）では，核上部にミトの分布密で短罩状のほか顆粒状を呈するも のを認め，殊飞12週では小皮縁下密集せる濃染層を形成している．之に 反し核下部飞於いては長桿状，糸状が主体をなし，粗い分布を示している. 斯かる相違は上皮細胞が核上部と核下部に於いて，機能的飞多少異なった ところあるのを暗示しているのでなかろうか．然しその咩細と就いては明 かにすることは出来ない，次飞 6 少月で細胞質 R. N. A. が著しく多量の時 は，ミトは減数して太い短桿状を呈し，一部に聚落を形成する。かくて7 ケ月の終りょり 9 ケ汭ばミトは増数し, 長短桿状, 糸状のものが核 上部，核下部飞集合して，成人のそれ飞近似し，こ〉飞小腸上皮の分化は 完成されるものと考光られる，有馬飞依れば，人胎览の小腸上皮飞顆粒状 ミトが認められ，桿状は稀であると述べているが，私の所見はむしろ桿状 ミトが多く氏とは全く逆の所見である.

他方興味深きは基底顆粒細胞である．抑る本細胞の特徵たる微小顆粒は， 主として細胞の基底部に充満するに反し，上半部は非常に狭㓌で短かく腸 の内挖飞達するものは少ない. Patzelt（1883）及び Friedmann（1934） は胎生期飞於いて本細胞を報告しているが，歴然たる顆粒を認めていな い. 之は恐らくは初期像であって, 後に顆粒が現われると云う位の説明で あって，その出現時期等に就いては記載がない，然るに私の例では12週に て初めて現われ，而もこのとき已と幼若型はもとより，成熟型と近いるの 
迄各種の形状及び構造を示している許りでなく，かねて問題とされている 本細胞の由来に関し稍々自信を持つに至った．即ち本細胞特有の微小顆粒 を僅か、有する細胞が，このとき間葉層（後来の粘膜固有層）の中に現わ れる，このものは恐らくは基底顆粒細胞の最初期のもので，これが上皮底 面飞接着し，次いで上皮の中飞進入し，そこにて本細胞特有の形態を有す ると至ることは，幾多の中間型により推定することが出来る．之と依り古 来論ぜられていた本細胞起源は, 間葉層飞求むべきであって, 上皮から分 かれてきたものでないと考它得る，尚この様に出現の当初から本細胞の核 下部には，微小顆粒と共に明視性空胞の存在するもの，また微小顆粒が殆 ぞ消失して空胞と䋊細なるミトのみを有するもの等あり, 従ってこのとき 已と何等かの機能を営んでいることは想像に難くない。

\section{IV. 結語}

胎生 こケ月より 9 ケ月飞至る人胎児小腸上皮の発生分化を，細胞微細構 造及び組織化学の面より系統的飞観察して次の如き結果を得た.

1. 胎生 8 週の上皮細胞は境界不明で，核は中央部に於いて $3-4$ 個が 重積し，胞体内飞は空胞が多い。これより上皮は急速飞肥厚し，一時内腔 が閉塞されるが，12週にて内腔再び通過性となる。一方上皮の細胞境界 もとの頃より判明し，漸次単層化すると同時飞，内腔側飞小皮縁が現われ る.

2. 絨毛の形成は12週で始まる。乙れは上皮の単層化と同時に起る間葉 層の上向発達によるものであるが，この単層化先行して上皮内部に次の 様な変化が起る．即ち $2-3$ 層であった上皮細胞㤥が，先づ単層となって 上皮の内腔側に一列に並び，次いで基底側に位置を変ずる，これと反し空 胞は基底側より内腔側と移る。而して細胞の境界は上皮の内挖側から始ま り基底側飞及ぶ。

3.4 ケ月の始め頃より䋐毛は急速飞発育し，小皮縁は全域に形成され， つねと絨毛尖端部より分化が進む．かくて 6 ケ月頃から著しい増長，增数 を示し，7ケ月の終り頃には生後のものに近似する。尚 7 ケ月迄上皮細胞 内、恀多くの空胞が認められるが，之は糖原及び脂肪染色飞陰性であって， その本体は判然としない.

4. リボ核酸を主体とする粗大顆粒が，上皮の単層化する 3 ケ月の終り そ於いて，絨毛尖端部細胞の核上部に現われる。このものは 6 ケ月で著明 飞増量して，胎生期中の極期を示すが，7ケ月の終りでは全く消失する. このリボ核酸の出現は, 上皮の発育分化の過程飞密接なる関係あるものと 
思われるが，その詳細を明かとすることは出来ない．

5. 上皮細胞の糸粒体は桿状，糸状が主体をなしている. 然し小皮縁が 形成され始め，また核が細胞上端部を占める 3 ケ月の終り飞於いて，顆粒 状糸粒体が核上部に密集して特殊配列を示すことは，この期の上皮分化に 関係あることを否めない，更と４ケ月より5ケ月の間とあっては，核上部 飞分布密で顆粒，短桿状が多く，核下部では糸状，桿状が主体で粗く分布 することは，核上部と核下部に於いて機能の異なることを物語っている． 次にリボ核酸の多量なる時は，糸粒体は太くなって減数し，稀に聚落を形 成しているに過ぎない，而してこれがなくなると糸粒体は増数し，核上部， 核下部に集合して生後のそれに近似する等は，何れも糸粒体が細胞分化に 対し重大なる役割を演じていることが想像に難くない.

6. 杯細胞は 3 ケ月の終りより散在的飞現われ，5ケ月以後は急激に增 数し，9ケ月にては腸腺内にも之を認める.

7. Paneth 氏細胞は 6 ケ月の終り飞初めて現われる。このとき已に幼 若型と思われるものより, 典型的構造を示するの及び空胞を有する機能像 も見られる. 爾後その数を増すが，9ケ月にては空胞を有するるの」增加 が著しい。

8. 基瓦顆粒細胞は間葉層中飞現われ，上皮中へ進入して発育する。 こ れは胎生 3 ケ月の終りと出現するが，この時成熟型を混ずる. 即ち細胞基 底部にある微小顆粒は空胞化し，その内容が放出されたと思劣るものが点 在する，尚本細胞の成熟型飞あっては，細胞上端が上皮表面に達している と考觉られるものも少なくない.

稿を終るにあたり，終始御愁篤なる御指導と御校閲を賜わりし恩即高木教授，貫 重なる材料の提供を们いだ日生病院長新海輝一博士に満腔の謝意を捹げます。

\section{Author's Abstract.}

The differentiation of intestinal epithelium in fresh human embryo from the 2nd month to the 9 th month were investigated systematically, from the points of both their fine cell structures and its histochemistry.

1. At the end of the 2nd month the limits between epithelial cells were indistinct and a pile of 3 to 4 nuclei were found in the middle of the cells, and in the cytoplasm numerous vacuoles were found. In these cells glycogen and fat stainings were unsuccessful. At the beginning of the 3rd month the epithelium thickened, because the epithelial cells piled up together and the intestinal lumen was blocked temporarily. At the end of the 3rd month, the intestinal canal became passable and the limits between cells became detectable again. The epithelial cells were 
then arranged in one layer, and at the same time the cuticular border appeared.

2. Formation of the villi began at the end of the $3 \mathrm{rd}$ month, because the mesenchyme developed into the lumen of the intestinal canal, and simplification of the epithelial layer occurred simultaneously. Epithelial cells changed prior to the simplification of the layer. Nuclei stood side by side and formed a line in the superficial portion of the epithelium and then move to the basal portion, but on the contrary, the vacuoles moved from the subnuclear zone to the supranuclear zone.

3. The villi began to grow rapidly at the end of the 4 th month, and then the cuticular borders were formed in all of the epithelial cells. Their development began from the tip of the villus. And their form became similar to those of adults at the end of the 7 th month.

4. Granules with ribonucleic aeid as their main constituent element appeared in the supranuclear portion of cells of the villus tip at the end of the 3rd month, and they remarkably increased during the $6 \mathrm{th}$ month and then disappeared by the end of the 7 th month. It is conceivable that the appearance of grains which contain ribonucleic acid has very much to do with the differentiation of epithelium, but its meaning is not yet clear.

5. Mitochondria in epithelial cells were very much rod-like or filament-like. At the end of the $3 \mathrm{rd}$ month when the cuticular border appeared the granular mitochondria became crowded in the supranuclear zone. Around the 4 th or the 5 th month the granular and rod-like mitochondria became densely distributed in the supranuclear zone, and the filamentous and rod-like mitochondria were loosely distributed. According to the above-stated observations we can imagine that the cells perform several different functions in the supranuclear and subnuclear zone. The number of mitochondria decreased when ribonucleic acid was plentifully in the cytoplasm. It is probably significant that mitochondria became numerous at the end of the 7 th month and that their form became like those in adults.

6. Goblet cells appeared at the end of the 3rd month, and they suddenly increased from the 5 th month, and were still found in the intestinal glands during the $9 \mathrm{th}$ month.

7. PANETH cells appeared for the first time at the end of the $6 \mathrm{th}$ month, and about this time there were already seen in several forms, such as unriped cells, as a typical granulous cell or as vacuolous cells. PANETH cells increased in number, and in the 9 th month vacuolated ones were particularly rich.

8. Basalgranular cells appeared in the mesenchymal layer and penetrate into the epithelium as they developed. They appeared for the first 
time at the end of the $3 \mathrm{rd}$ month, and ripe cells were found with unriped ones at the same time. The apex of the ripe cell reached the surface of the epithelium.

\section{文献.}

Arima: Untersuchungen am Darm des Menschenembryos. Fol. anat. jap. 5 (1927). - Berry : On the development of the villi of the human intestine. Anat. Anz. 17 (1900). S. 242. - Brachet: Nucleic acids in the cell and the embryo. Symp. Soc. exp. Biol. 1 (1947). P. 207. - Clara: Untersuchungen über die basalgekörnten Zellen des Schweines. Z. mikr. -anat. Forsch. 30 (1927). Fischel: Entwicklung des Menscȟen. 1929. S. 338. - Friedrann: Beiträge zur Kenntnisse der basalgekörnten, gelben Zellen des Darmtraktus beim Menschen. Z. mikr. -anat. Forsch. 36 (1934). - Hamperl: Über die gelben Zellen im Epithel des Verdanungstraktus. Arch. mikr. Anat. 81 (1924). 一 原货 一：人胎韭消化管の発生学的研究. II. 解剖誌. 4 (1931). 一 Kölliker: Entwicklungsgeschichte des Menschen. 1861. S. 1-468. - Kreuter: Die angeborenen Verschließungen und Verengerungen des Darmkanals im Lichte der Entwicklungsgeschichte. Dtsch. Z. Chir. 79 (1905). - Meckel: Bildungsgeschichte des Darmkanals der Säugetiere und namentlich des Menschen. Dtsch. Arch. Physiol. 3 (1817). S. 1. 一 奧田政一：十二指腸粘膜に於ける chromaffine Zellen の細胞兴 的研究. 解剖誌. 8 (1935). 一 大森參里：日本人广二指腸の胎生期飞於ける形態出 飞組識兴的研究. 解剖誌. $3(1930)$. 一 瀨木三雄：人胎児䋐毛に於けるクローム親 和性細胞団よりなる特殊棈浩飞就いて。解剖誌. 8 (1935). — T andler：Zur Entwicklungsgeschichte des menschlichen Duodenum in frühen Embryonalstadien. Morph. Jahrb. 29 (1900). S. 187.

\section{附 図說 明.}

細胞四は Zeiss $100 \times$ (n. a. 1.30)，Zeiss $10 \times$ を用い，筒長は常に $160 \mathrm{~mm}$ とし， Abbe の描写器を以て作業机上飞投影描写した.

\section{Explanation of Plates.}

Figg. 1-6, 9-11, 15, 17 and the figures on the last plate figures are the reproductions obtained with $\mathrm{ABBE}$ 's apparatus. 
小腸上皮細胞。

附为 I. Heidenhain 鉄 Hematoxylin 染色飞よる小腸上皮細胞微細輔造. 1, 000 x 図1. 胎生 2 ケ月の終り ( 8 週).

四 2. 胎生 3 ケ月の初期 (10週).

四 3-5. 胎生 3 ケ月の終り (12週). 3 絨毛基底部, 4 䋐毛中央部, 5 絨毛突端部.

Intestinal epithelial cell.

Plate I. The fine structures of intestinal epithelial cells, stained with HEIDENHAIN's iron hematoxylin. 1,000 $x$

Fig. 1. At the end of the 2nd month.

Fig. 2. At the beginning of the 3rd month.

Fig. 3-5. At the end of the 3rd month. 3 Base of villi, 4 Middle of villi, 5, Apex of villi. 

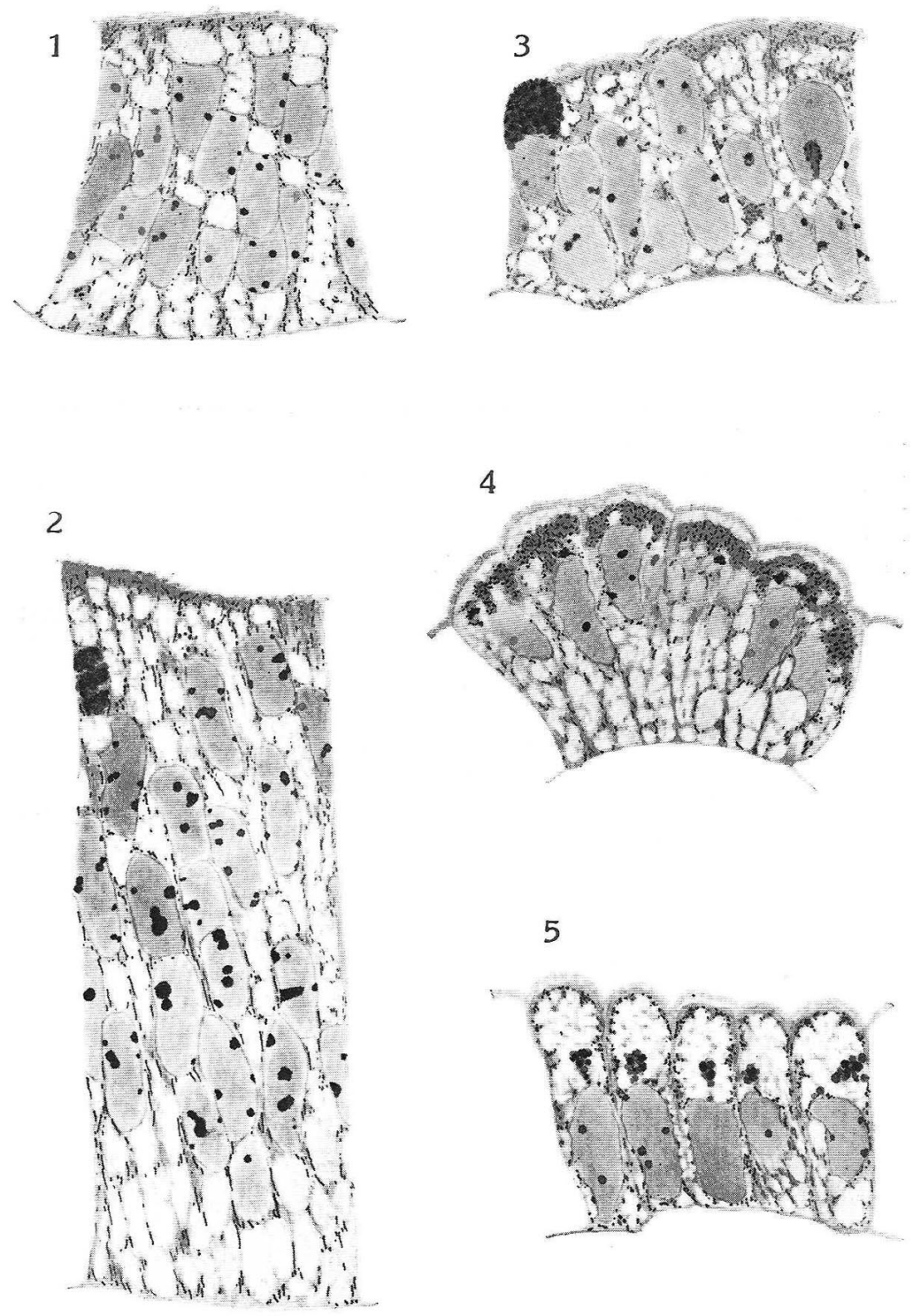

5

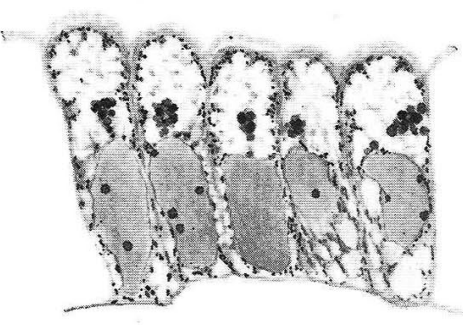


附図 II. Pyronin-methyl green 染色飞よる小腸上皮細胞質 R. N.A. 1,000×

四6. 胎生 4 ケ月の終り,

図 9 . 胎生 6 ケ月.

図 11. 11胎生 7 ケ月初期.

図 7. 胎生 5 ケ月に於ける小腸の横断面。 $45 \times$

四 8 と 10. 胎生 6 ケ月に於ける微細構造.

Plate II. The cytoplasmic ribonucleic acid, stained with pyronin-methyl green. $1,000 \times$

Fig. 6. At the end of the 4th month.

Fig. 9. The 6th month.

Fig. 11. At the beginning of the 7 th month.

Fig. 7. Cross-section of intestine in the 5 th month. $45 \times$

Fig. 8 a. 10. The fine structure of intestinal epithelial cells in the 6th month. 
小腸上皮細胞（II）
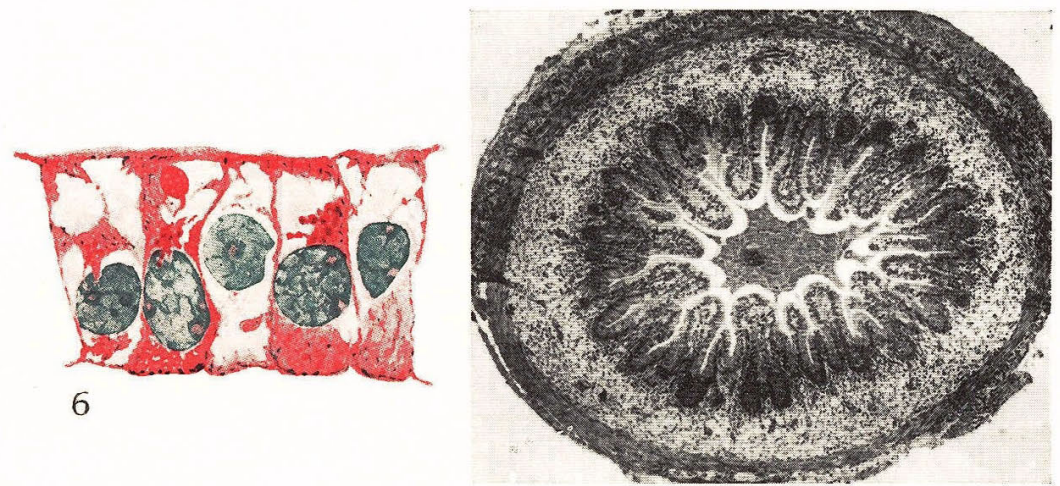

7
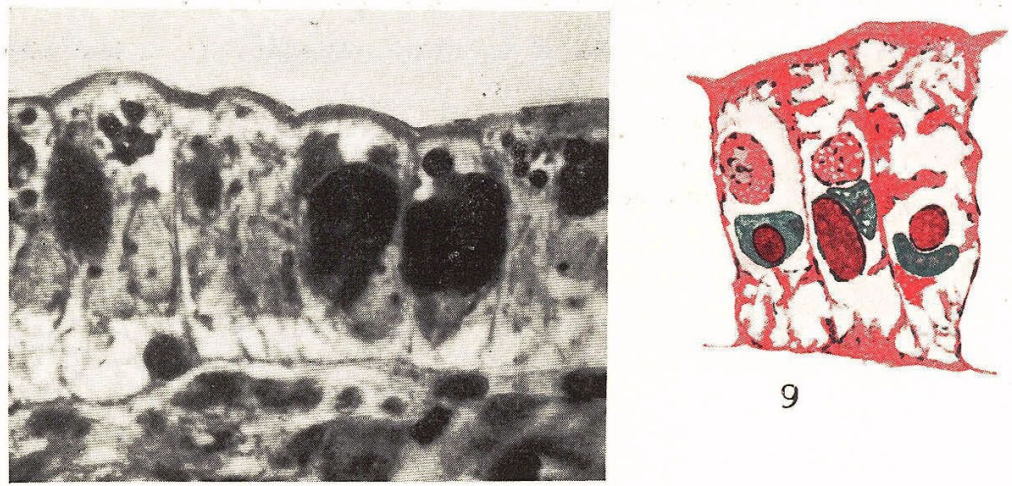

9

8
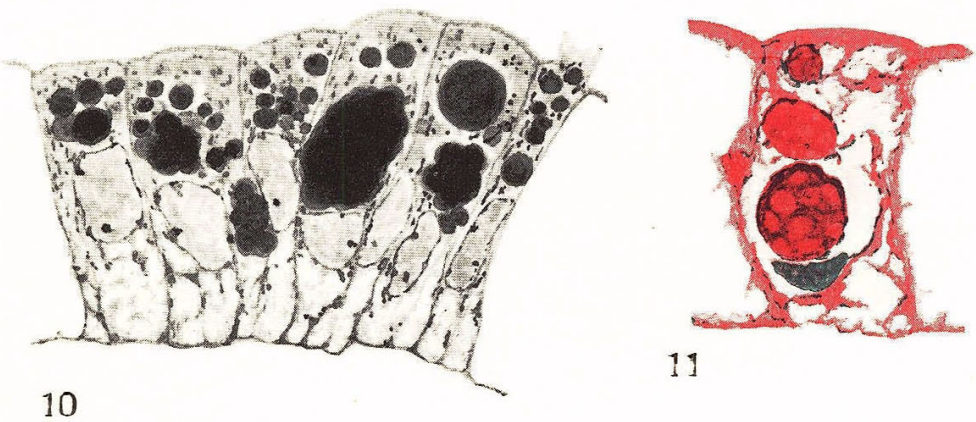

11 


\section{附図 III.}

四 12 と 13. Paneth 氏細胞.

図 14 と 15. 胎生 7 ケ月末期と於ける小腸上皮細胞、イトコンドリアと杯細胞.

㘠 16 と 17 . 胎生 9 ケ月飞於ける小腸上皮細胞マイトコンドリア.

Plate III. The fine structures of intestinal epithelial cells, stained with HEIDENAIN's iron hematoxylin. 1,000x.

Fig. 12 a. 13, PANETH cell.

Fig. 14 a. 15, At the end of the 7 th month.

Fig. 16 a. 17. The 9 th month. 
小腸上皮組胞（林）

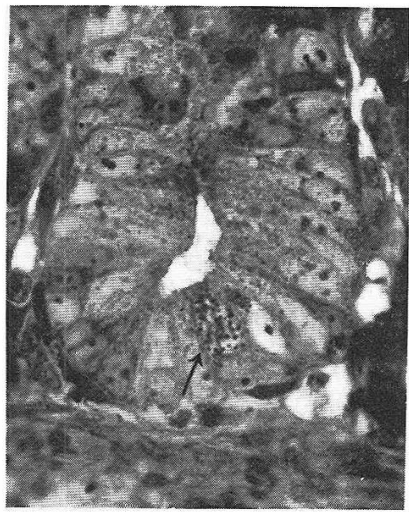

12

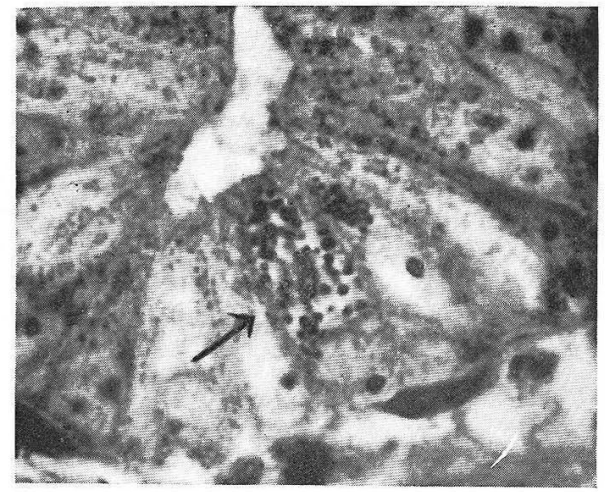

13
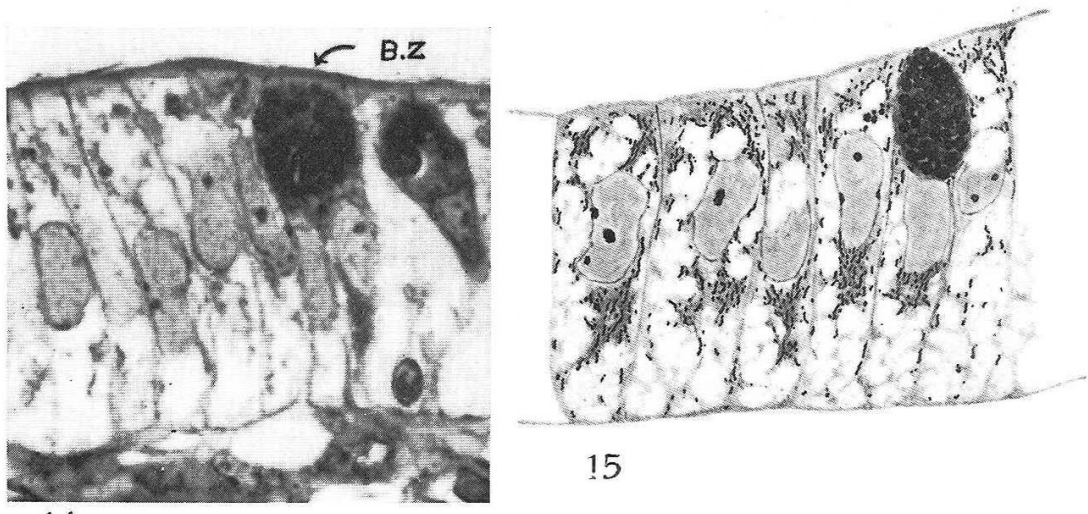

15

14
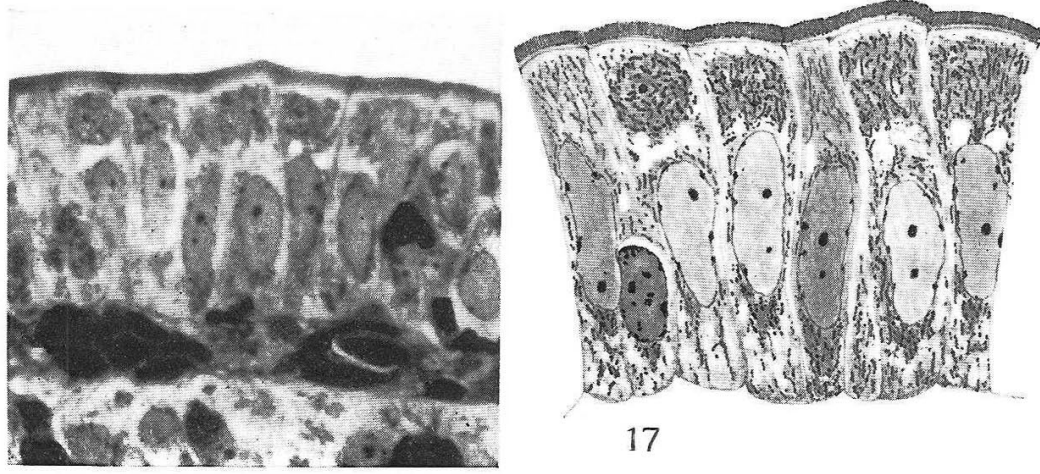

16

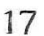




\section{基底顆粒細胞.}

Heidenhain 鉄 Hematoxylin 染色飞よる基底顆粒細胞. 1,000× 図 1 と 2 . 成熟型.

因 $3,4,5$. 機能型.

図 6, 7,8. 幼若型.

Basalgranular cells

Basalgranular cells, stained with HEIDENHAIN's iron hematoxylin. 1,000× Fig. 1 a. 2. typical forms.

Fig. 3, 4 a. 5 . functional forms,

Fig. 6, 7 a. 8. A unripened form. 
基底顆粒細胞
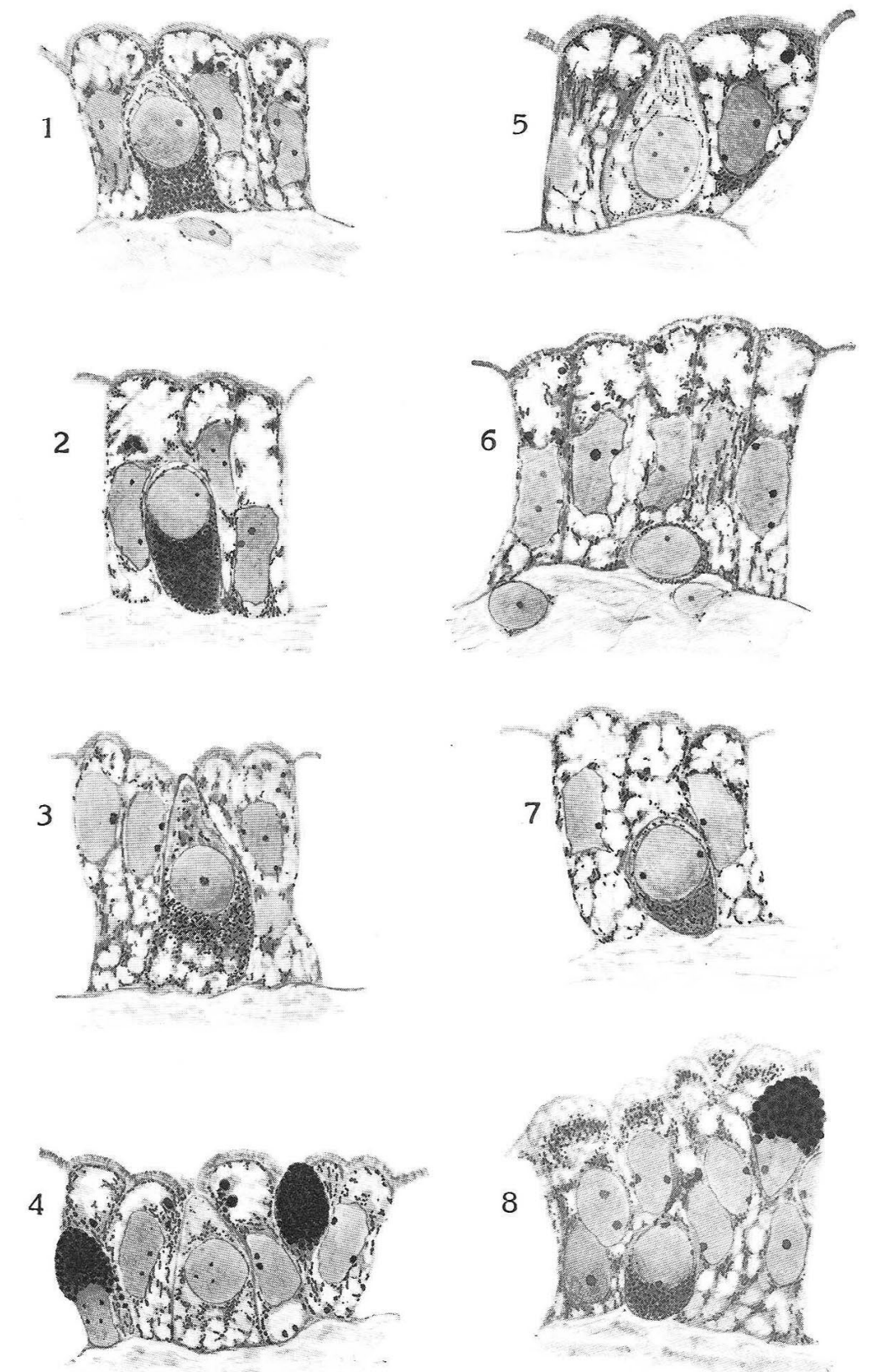